\title{
Psoriasis and sexual dysfunction: links, risks, and management challenges
}

This article was published in the following Dove Press journal:

Psoriasis: Targets and Therapy

\section{Gleison V Duarte' \\ Humberto Calmon ${ }^{2}$ \\ Gabriela Radel ${ }^{2}$ \\ Maria de Fátima Paim de \\ Oliveira $^{3}$ \\ 'Department of Dermatology, Instituto Bahiano de Imunoterapias (IBIS), Bahia, Brazil; ${ }^{2}$ Universidade Salvador, Bahia, Brazil; 'DERMAPP, Bahia, Brazil}

Correspondence: Gleison V Duarte Department of Dermatology, Instituto Bahiano de Imunoterapias (IBIS), Avenida Tancredo Neves 620, Caminho das Árvores, 41820-020 Salvador, Bahia, Brazil

Tel +55 7l 3565 069l/30I23755

Email gleisonvduarte@yahoo.com.br

\begin{abstract}
According to the WHO, sexual health is not merely the absence of disease. Sexual dysfunction may be present in $40.8 \%$ of psoriasis patients, furthermore, $68 \%$ prevalence was found in Brazilian women with psoriasis. The moderate prevalence of psoriatic lesions in the genital area $(35 \%-42 \%)$ does not explain the alarming prevalence of sexual dysfunction. Other factors, such as anxiety, depression, and also psoriasis treatment may contribute to its development. Likewise, atherosclerosis of the pelvic vasculature is involved in the pathogenesis of erectile dysfunction. Risk factors for erectile dysfunction tend to be confused with the comorbidities seen in psoriasis patients. We also highlight that it may serve as a marker of cardiovascular risk. Keywords: psoriasis, erectile dysfunction, sexual health, comorbidity
\end{abstract}

\section{Introduction}

Psoriasis, a systemic immune-mediated disease, involves chronic inflammation triggered by psychological, genetic, and environmental factors. The reported prevalence of psoriasis globally ranges between $0.09 \%$ and $11.43 \%,{ }^{1}$ while its prevalence in Brazil is estimated to be $1.3 \%{ }^{2}$

Multiple comorbidities such as diabetes mellitus, atherosclerotic disease, metabolic syndrome, and symptoms such as anxiety, as well as lifestyle habits such as smoking, have been associated with psoriasis. ${ }^{3}$ Feelings of embarrassment, low self-esteem, and stigmatization are common in psoriasis patients and contribute to avoiding starting a family or having children due to the possibility of inheriting the disease. ${ }^{4}$ Moreover, several studies suggest that depression plays a significant role in increased morbidity among patients. ${ }^{5,6}$ Furthermore, the physical, social, and psychological impact of psoriasis is considerable, and as in other chronic diseases, this negative impact may contribute to sexual dysfunction. ${ }^{?}$

Sexual health is defined by the WHO as a state of physical, emotional, mental, and social well-being in relation to sexuality, and not merely the absence of disease, dysfunction or illness. ${ }^{8}$ A pioneering study conducted in 1997 showed sexual dysfunction to be present in $40.8 \%$ of psoriasis patients, even after controlling for potential confounders such as alcohol consumption and depression. Although other studies followed, ${ }^{9}$ and despite the fact that a fourth of all psoriasis sufferers, both men and women, report a reduction in their sexual activity after developing the disease, the effect of psoriasis on sexual health remains to be fully clarified. ${ }^{10}$

Other skin disorders such as lichen simplex chronicus, chronic hand eczema, vitiligo, and chronic urticaria have also been associated with a greater risk of sexual 
dysfunction. ${ }^{11-13}$ The Dermatology Life Quality Index includes a question that evaluates the extent to which an individual's skin disorder has caused him or her sexual difficulties in the preceding week. Psoriasis and hidradenitis suppurativa have been shown to be among the five skin disorders for which the highest scores are obtained for that specific question. ${ }^{14}$

The effect of psoriasis on sexual health may be linked to several factors, including the detrimental effect of the condition on the individual's physical appearance, decreased libido, and the inconvenience caused both by skin desquamation and by topical treatment. ${ }^{10}$ In men with psoriasis and erectile dysfunction, these risk factors may be overlooked due to the presence of a sedentary lifestyle and associated comorbidities such as dyslipidemia, hypertension, diabetes, obesity, metabolic syndrome, and depression. ${ }^{15,16}$

The present review article aimed to alert clinicians and dermatologists to the potential presence of sexual dysfunction in these patients and the possible aggravators related to psoriasis itself, to its comorbidities, and to the pharmaceutical drugs used to treat the disease.

\section{Female sexual dysfunction in psoriasis}

The skin manifestations of psoriasis make this a highly visible disease, causing the patient to feel stigmatized. Many women report some degree of difficulty in their sex life, ultimately resulting in intense personal distress and decreased quality of life. ${ }^{17}$ Despite being frequent, with one study having found a $68 \%$ prevalence of sexual dysfunction in 150 Brazilian women with psoriasis, ${ }^{18}$ few studies have been conducted on the subject and there is no consensus regarding the causes of the dysfunction or the best instrument for its evaluation.

The widely used questionnaire, Female Sexual Function Index (FSFI), evaluates six sexual function domains: desire, arousal, lubrication, orgasm, satisfaction, and pain. Of 102 British women with psoriasis evaluated using the FSFI, sexual dysfunction was found in $48.7 \% .{ }^{10}$ All the domains of the FSFI except lubrication and pain appear to be significantly affected in patients with psoriasis; ${ }^{19}$ however, of all the domains, sexual desire may be the one most affected. ${ }^{18}$

The part of the body affected by psoriasis may play an important role in the development of sexual dysfunction, with skin lesions on the genital areas, thighs, abdomen, and back being significantly associated with sexual dysfunction. ${ }^{20}$ The prevalence of genital lesions at any time during the course of psoriasis, as detected by physicians during examination or reported by patients answering a questionnaire, ranged from $33 \%$ to $63 \%$. The baseline data of two randomized controlled trials showed a prevalence of psoriatic lesions in the genital area of $35 \%$ and $42 \% .{ }^{21}$ Some authors have argued that genital lesions alone do not directly hamper sexual function but may rather cause sexual distress in women, who tend to feel less physically attractive because of their skin lesions. ${ }^{10}$

The severity of psoriasis may also contribute to sexual dysfunction. Overall, sexual dysfunction was reported in $31.6 \%$ of a population of patients with psoriasis. Although not statistically significant, the proportion of dysfunction was greater in those with severe psoriasis compared to those with mild or moderate forms of the disease. ${ }^{22}$ Likewise, patients who achieved a greater improvement, as evaluated by the Psoriasis Area and Severity Index, experienced a greater reduction in the sexual difficulties caused by psoriasis, ${ }^{23}$ suggesting an association between the severity of psoriasis and sexual dysfunction.

Other factors that could explain the high prevalence of sexual dysfunction in psoriasis patients refer to physical signs and symptoms such as stinging, bleeding, and desquamation, and psychological disease as depression and symptoms such as anxiety. Joint involvement, the severity of pruritus, and higher depression scores have all been reported to be associated with impaired sexual function. ${ }^{24}$ Depression was proposed as a crucial psychological link between psoriasis and sexual dysfunction. The prevalence of anxiety and depression was found to be higher in psoriasis patients compared to the general population..$^{20}$ The elevated levels of TNF- $\alpha$ and IL-1 involved in the pathogenesis of psoriasis could also be associated with depression. ${ }^{23}$ Sexual dysfunction appears to be more common in patients with psoriasis compared to those with neurodermatitis, with a positive correlation between sexual dysfunction and depression. ${ }^{25}$ Nevertheless, one study suggested that coexisting depression does not exert any additional negative effect on sexual function in psoriasis patients. ${ }^{18}$ This apparent contradiction could be explained by the fact that psoriasis can result in changes to the individual's perception of body image, feelings of low self-esteem, perceived stigmatization, and loss of confidence, which can lead to sexual dysfunction irrespective of depression. ${ }^{26}$ Therefore, insofar as psychological factors are concerned, whether they result from depression or a change in the perception of body image, what is clear is that psoriasis affects the psyche and, in a chain reaction, these patients' sexual function.

Disease control in psoriasis can restore quality of life and sexual function. A significant reduction in sexual difficulties was reported by patients treated with ustekinumab compared to those treated with placebo. ${ }^{24} \mathrm{~A}$ mean improvement of 6.3 points in the FSFI was found, with notable changes in the 
domains of satisfaction and arousal following biological therapy. ${ }^{27}$

Agreement among authors regarding the occurrence of sexual dysfunction in women with psoriasis appears to be unanimous; however, the hypotheses put forward to explain these findings remain controversial and incomplete. Based on the few studies available and despite considerable controversies, the need to pay close attention to the psychological effects caused by psoriasis is unquestionable. This is evident from the finding that at least $43 \%$ of psoriasis patients believe doctors do not pay enough attention to the possibility of sexual problems. ${ }^{10}$ The fact that this type of symptomatology has been overlooked in medical practice has been highlighted, and physicians have been strongly advised to evaluate the impact of psoriasis not only in relation to skin and joint comorbidities, but also in relation to psychosocial and sexual issues. ${ }^{18}$

\section{Male erectile dysfunction in psoriasis}

Erectile dysfunction is defined as persistence of the inability to achieve and/or maintain an erection during sexual activity, and is one of the health factors that has a greater impact on masculine self-esteem, causing loss of confidence, in addition to stress and depression. ${ }^{28,29}$ Rejection because of psoriasis is experienced by $44.7 \%$ of men and feeling unattractive or embarrassed during psoriasis exacerbation can aggravate low self-confidence and erectile dysfunction. ${ }^{16}$ Atherosclerosis, which affects the vasculature of the pelvis, is considered the major cause of this dysfunction in males. Besides vascular factors, patients' lifestyle and psychosocial factors may also explain the presence of erectile dysfunction in psoriasis patients. ${ }^{30,31}$ Moreover, hormonal disturbance may be the reason for the significantly impaired erectile function. Psoriasis patients present decreased levels of total testosterone and increased levels of estradiol. ${ }^{32}$ Furthermore, erectile dysfunction tends to become more severe and more prevalent with age or duration of the disease in the case of chronic systemic illnesses. ${ }^{32,33}$

A common condition in dermatology patients, the prevalence of sexual dysfunction is approximately $60 \%$ when evaluated using the International Index of Erectile Dysfunction-5 item questionnaire. ${ }^{34}$ Risk factors for erectile dysfunction tend to become confused with the comorbidities seen in psoriasis patients such as dyslipidemia, hypertension, diabetes, obesity, metabolic syndrome, and depression, and also with the effects of a sedentary lifestyle (Figure 1). ${ }^{35-40}$

Irrespective of diabetes and the habit of smoking, erectile dysfunction is a marker of cardiovascular risk, with a risk level that is similar to that of a moderate smoker. ${ }^{41,42}$ Therefore, early diagnosis can serve as a warning sign of occult cardiovascular disease. ${ }^{41,42}$ One study estimated the time between the onset of erectile dysfunction and the occurrence of cardiovascular events at 3-5 years. ${ }^{43}$

Psoriasis has been identified as an independent risk factor for sexual dysfunction, with the risk being even higher in patients with concomitant psoriatic arthritis. Systemic

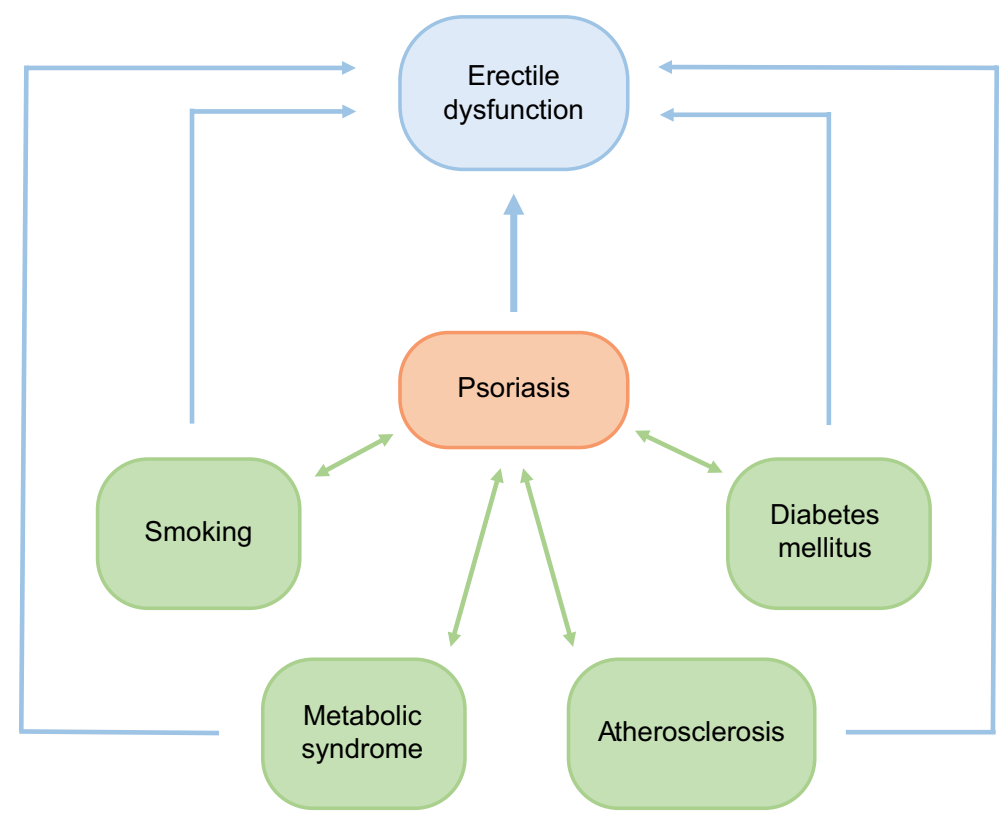

Figure I Association between erectile dysfunction, psoriasis, and comorbidities. Notes: Blue arrows: independent association. Green arrows: comorbidities. 
inflammation contributes to endothelial dysfunction and consequently affects vascular function, the core of the pathogenesis of erectile dysfunction. ${ }^{44}$ Surprisingly, one study found erectile dysfunction in $56 \%$ of individuals with mild psoriasis, in $46.6 \%$ of those with the severe form of the disease, and in $23.3 \%$ of a control group. ${ }^{45}$

Psoriasis patients, particularly those with psoriatic arthritis or severe psoriasis, are most probably at greater risk of periodontitis. ${ }^{46,47}$ Periodontitis is an important risk factor for cardiovascular disease, which in turn is strongly correlated with erectile dysfunction. In a mouse experimental model, the induction of periodontitis was associated with erectile dysfunction in the absence of cardiovascular disease and/or ultrastructural changes in the corpora cavernosa. ${ }^{48}$ Indeed, there is a bidirectional relationship between psoriasis and periodontitis, where systemic inflammation produced by psoriasis may increase the severity of periodontitis, and this focus of infection acts as a triggering factor for psoriasis. ${ }^{49}$ Furthermore, periodontal disease causes vascular endothelial infection, local increase of white cells, tissue growth factors and endotoxins, favoring atherosclerosis and erectile dysfunction. ${ }^{50}$

\section{Does psoriasis treatment affect sexual health?}

The treatment of psoriasis and its comorbidities can have a negative effect on sexual health. Although there are few studies on the subject, topic and systemic treatment for psoriasis can be considered a trigger of male and female sexual dysfunction. As topical medications used in psoriasis vulgaris can also be used in genital psoriasis, attention should be paid to minimize the risks of irritation and toxicity. Lower potency topical corticosteroids or calcitriol, a less irritating vitamin $\mathrm{D}$ analog, may promote less irritation or skin atrophy of the genital area, causing a smaller impact on sex life than higher potency topical corticosteroids. ${ }^{51,52}$

Etretinate/acitretin and methotrexate have been associated with sexual and erectile dysfunction..$^{25,42}$ The drugs used to treat psoriasis comorbidities, in addition to the drugs used to treat the disease itself (Table 1), could also exert a negative effect on sexual function. These include antidepressants, muscle relaxants, non-steroidal anti-inflammatory drugs, H1 antagonists, proton pump inhibitors, anxiolytics, and several antihypertensives (beta-blockers, alpha blockers that act on the central nervous system, thiazides, and spironolactone). ${ }^{9}$

Methotrexate is one of the drugs used specifically to treat psoriasis. The methotrexate package insert refers to "extremely rare" side effects in the sexual realm, including impaired spermatogenesis, decreased libido and infertility; however, the exact mechanisms of action are unknown. Cases of erectile dysfunction and gynecomastia have also been described. ${ }^{53}$ Hypotheses range from decreased nitric oxide production to a direct effect on the pituitary gland and on prolactin secretion. ${ }^{54,55}$ A study conducted with patients with inflammatory bowel disease appears to substantiate the effects of methotrexate on sexual function, implicating this drug and sulfasalazine in reversible dysfunctions and infertility. ${ }^{56}$

Retinoids such as acitretin, etretinate, and isotretinoin have been implicated in various reports of reversible induced erectile dysfunction, possibly impacted by the presence of symptoms of depression. ${ }^{57-59}$ Furthermore, according to a prospective, 1-year study conducted with 196 women aged 15-45 years, women using acitretin are more prone to vulvovaginal candidiasis, possibly as the result of cumulative exposure to the drug. ${ }^{60}$

Cyclosporine, one of the conventional drugs, appears to be less associated with sexual dysfunction; however, a greater frequency of adverse events has been reported in women, particularly postmenopausal women. ${ }^{61}$ On the other hand, of the biological drugs, evidence from studies conducted with patients with ankylosing spondylitis and psoriasis appears to show that patients using anti-TNF therapy, anti-IL-17A or ustekinumab have a better quality sex life, probably due to having achieved or almost achieved remission of the disease. ${ }^{27,62,63}$

\section{Final comments}

Psoriasis is a stigmatizing disease that impairs quality of life and harms self-esteem through its effect on social relationships and self-perception, with a negative impact on physical, mental, and sexual health. Psoriasis sufferers, both male and female, are known to be at an increased risk of impaired sexual function. Several hypotheses have been raised to explain the relationship between psoriasis and sexual dysfunction, both of which represent independent risk factors for cardiovascular disease. Therefore, a broader investigation into sexual and cardiovascular health should be incorporated as routine by clinicians and dermatologists when treating a patient with psoriasis, with the comorbidities known to be present in these patients also being taken into consideration. Furthermore, the dermatologist should be aware that psoriasis treatment could improve or impair the patient's sexual function. Finally, psoriasis patients need to talk about their sex life and it is up to the dermatologist to be attentive to this need, since these sexual problems are generally not dealt with at consultations. Sexual dysfunction thus serves as an alert to the need for a multidisciplinary approach in psoriasis. 
Table I Drugs used to treat psoriasis and their impact on sexual health

\begin{tabular}{|c|c|c|c|c|}
\hline Drug & Type of study/pathology & Participants & Findings & Reference \\
\hline Cyclosporine & $\begin{array}{l}\text { Cohort, observational. } \\
\text { Psoriasis. }\end{array}$ & $\begin{array}{l}969 \text { adults with } \\
\text { psoriasis. }\end{array}$ & $\begin{array}{l}\text { No statistically significant difference in side effects } \\
\text { between the sexes, paired for age. Slight tendency } \\
\text { in females. Incidence rate in fertile vs menopausal } \\
\text { women of } 0.67 \text { ( } 95 \% \mathrm{Cl}: 0.49-0.92) \text {. }\end{array}$ & 61 \\
\hline Etretinate & $\begin{array}{l}\text { Case report: two patients } \\
\text { using etretinate, } 37 \text { and } \\
40 \text { years of age, both with } \\
\text { a history of depression. } \\
\text { Psoriasis. }\end{array}$ & $\begin{array}{l}\text { Males, } 37 \text { and } 40 \\
\text { years of age, both } \\
\text { with a history of } \\
\text { depression. }\end{array}$ & $\begin{array}{l}\text { One patient improved after discontinuing use. The } \\
\text { drug was not reintroduced. The second suffered a } \\
\text { recurrence of symptoms after drug reintroduction. }\end{array}$ & 58 \\
\hline Acitretin & $\begin{array}{l}\text { Case report: male patient, } 39 \\
\text { years of age. Psoriasis. }\end{array}$ & $\begin{array}{l}\text { Male, } 39 \text { years of } \\
\text { age. }\end{array}$ & $\begin{array}{l}\text { ED and absence of morning erection during } 45 \\
\text { days of use. Reversal of symptoms following } \\
\text { discontinuation. }\end{array}$ & 57 \\
\hline $\begin{array}{l}\text { Acitretin, } \\
\text { methotrexate, } \\
\text { and cyclosporine }\end{array}$ & $\begin{array}{l}\text { Population-based study. } \\
\text { Psoriasis. }\end{array}$ & $\begin{array}{l}\mathrm{I} 2,300 \text { men with } \\
\text { psoriasis and } 6 \mathrm{I}, 500 \\
\text { controls. }\end{array}$ & $\begin{array}{l}\text { Increased risk of sexual dysfunction in psoriasis } \\
\text { patients compared to controls, principally if } \geq 60 \\
\text { years of age compared to those }<60 \text { years of age and } \\
\text { in the presence of PsA. Risk not significantly higher in } \\
\text { patients using systemic drugs. }\end{array}$ & 44 \\
\hline Methotrexate & $\begin{array}{l}\text { Case report: two patients. } \\
\text { Psoriasis. }\end{array}$ & $\begin{array}{l}\text { Males, } 58 \text { and } 68 \\
\text { years of age. }\end{array}$ & $\begin{array}{l}\text { Patient I: symptoms of ED after } 2 \text { weeks. Symptoms } \\
\text { abated } 4 \text { weeks after switching to acitretin. } \\
\text { Patient 2: decreased libido and ED within } 3 \text { weeks of } \\
\text { use. Symptoms abated } 3 \text { weeks after discontinuation. }\end{array}$ & 54 \\
\hline Methotrexate & $\begin{array}{l}\text { Case report: two patients. } \\
\text { Psoriasis. }\end{array}$ & $\begin{array}{l}\text { Patients } 5 \mathrm{I} \text { and } 54 \\
\text { years of age. }\end{array}$ & $\begin{array}{l}\text { Patient I: ED with no reduction in libido within } 3 \\
\text { weeks of use. Symptoms abated after switching to } \\
\text { infliximab. } \\
\text { Patient 2: methotrexate discontinued after } 9 \text { months } \\
\text { due to intermittent ED and decreased libido. } \\
\text { Symptoms abated after drug discontinuation. }\end{array}$ & 64 \\
\hline $\begin{array}{l}\text { Anti-TNF- } \alpha \\
\text { antibody therapy }\end{array}$ & $\begin{array}{l}\text { Open, placebo-controlled } \\
\text { study: } \\
42 \text { patients. }\end{array}$ & $\begin{array}{l}\text { Ankylosing } \\
\text { spondylitis and } \\
\text { controls. }\end{array}$ & $\begin{array}{l}\text { Quality of sex life and disease activity improved in } \\
\text { the anti-TNF- } \alpha \text { group. Positive correlation between } \\
\text { improved quality of sex life and disease activity. }\end{array}$ & 62 \\
\hline $\begin{array}{l}\text { UST (an } \\
\text { anti-IL-I2/23 } \\
\text { monoclonal } \\
\text { antibody) }\end{array}$ & $\begin{array}{l}\text { Randomized, placebo- } \\
\text { controlled controlled trial. Post } \\
\text { hoc analysis between baseline } \\
\text { and week 12. Psoriasis. } \\
\end{array}$ & $\begin{array}{l}\text { I,334 patients in } \\
\text { the UST group and } \\
662 \text { in the placebo } \\
\text { group. }\end{array}$ & $\begin{array}{l}\text { Sexual dysfunction in } 27.1 \% \text { of the women and in } \\
20.8 \% \text { of the men. No reduction in dysfunction in } \\
\text { the placebo group. In the UST group, reduction from } \\
22.4 \% \text { to } 2.7 \% \text {. }\end{array}$ & 23 \\
\hline $\begin{array}{l}\text { Adalimumab and } \\
\text { etanercept }\end{array}$ & $\begin{array}{l}\text { Pilot study on sexual } \\
\text { dysfunction and the use of } \\
\text { biological treatment. Psoriasis. }\end{array}$ & $\begin{array}{l}10 \text { men and } 10 \\
\text { women. }\end{array}$ & $\begin{array}{l}\text { Women: improvement in FSFI score from } 22.43 \text { to } \\
28.73 \text {. } \\
\text { Men: improvement in IIEF score from } 51.5 \text { to } 60.75 \text {. }\end{array}$ & 27 \\
\hline $\begin{array}{l}\text { IXE (an anti-IL- } \\
\text { I7A antibody) }\end{array}$ & $\begin{array}{l}\text { Randomized, placebo- } \\
\text { controlled, Phase } 3 \mathrm{~b} \\
\text { controlled trial. Psoriasis. }\end{array}$ & $\begin{array}{l}75 \text { patients in the } \\
\text { IXE group and } 74 \text { in } \\
\text { the control group. }\end{array}$ & $\begin{array}{l}\text { IXE proved superior in the primary (genital psoriasis) } \\
\text { and secondary outcomes (pruritus, sexual frequency } \\
\text { questionnaire in genital psoriasis). }\end{array}$ & 63 \\
\hline
\end{tabular}

Abbreviations: ED, erectile dysfunction; FSFI, Female Sexual Function Index; IIEF, International Index of Erectile Function; IXE, ixekizumab; PsA, psoriatic arthritis; UST, ustekinumab; IL, interleukin.

\section{Disclosure}

GVD reports non-financial support from Abbvie, nonfinancial support from Janssen, non-financial support from Novartis, outside the submitted work. The authors report no other conflicts of interest in this work.

\section{References}

1. World Health Organization. Global report on psoriasis. WHO; 2016. Available from: http://apps.who.int/iris/bitstream/handle/10665/204417/9789241565189_eng.pdf;jsessionid=551AB596DD 1AC6471A6FEDB8E26F3A93? sequence=1. Accessed June 30, 2018.

2. Romiti R, Amone M, Menter A, Miot HA. Prevalence of psoriasis in Brazil - a geographical survey. Int J Dermatol. 2017;56(8): e167-e168.
3. Lowes MA, Bowcock AM, Krueger JG. Pathogenesis and therapy of psoriasis. Nature. 2007;445(7130):866-873.

4. Silva Kdes, Silva Eatda. Psoríase e sua relação com aspectos psicológicos, stress e eventos da vida. Estudos de Psicologia. 2007;24(2):257-266.

5. Mesquita PMA. Psoríase: Fisiopatologia e Terapêutica [dissertação]. Porto: Universidade Fernando Pessoa; 2013:31.

6. Jones JB. Psoriasis. Medicines. 2005;33(1):50-56.

7. Koo J. Population-based epidemiologic study of psoriasis with emphasis on quality of life assessment. Dermatol Clin. 1996;14(3):485-496.

8. World Health Organization - WHO [homepage on the internet]. Defining sexual health. Available from: http://www.who.int/reproductivehealth/ topics/sexual_health/sh_definitions/en_. Accessed June 30, 2018.

9. Gupta MA, Gupta AK. Psoriasis and sex: a study of moderately to severely affected patients. Int J Dermatol. 1997;36(4):259-262.

10. Meeuwis KA, de Hullu JA, van de Nieuwenhof HP, et al. Quality of life and sexual health in patients with genital psoriasis. Br J Dermatol. 2011;164(6):1247-1255. 
11. Mercan S, Altunay IK, Demir B, Akpinar A, Kayaoglu S. Sexual dysfunctions in patients with neurodermatitis and psoriasis. J Sex Marital Ther. 2008:34(2):160-168.

12. Ergün M, Türel Ermertcan A, Oztürkcan S, Temeltaş G, Deveci A, Dinç G. Sexual dysfunction in patients with chronic hand eczema in the Turkish population. $J$ Sex Med. 2007;4(6):1684-1690.

13. Sukan M, Maner F. The problems in sexual functions of vitiligo and chronic urticaria patients. J Sex Marital Ther. 2007;33(1):55-64.

14. Sampogna F, Abeni D, Gieler U, et al. Impairment of sexual life in 3,485 dermatological outpatients from a multicentre study in 13 European countries. Acta Derm Venereol. 2017;97(4):478-482.

15. Ji S, Zang Z, Ma H, et al. Erectile dysfunction in patients with plaque psoriasis: the relation of depression and cardiovascular factors. Int $J$ Impot Res. 2016;28(3):96-100.

16. Wojciechowska-Zdrojowy M, Reich A, Szepietowski JC, Wojciechowski A. Analysis of sexual problems in men with psoriasis. J Sex Marital Ther. Epub 2018 April 12.

17. Kurizky PS, Mota Lmhda, Mota Licia MHD. Disfunção sexual em pacientes com psoríase e artrite psoriásica - uma revisão sistemática. Rev Bras Reumatol. 2012;52(6):943-948.

18. Kurizky PS. Avaliação da ocorrência de disfunção sexual nas pacientes com psoríase e artrite psoriásica: um estudo tipo caso-controle de 150 mulheres brasileiras. Tese (mestrado em Ciências Médicas) - Faculdade de Medicina, Universidade de Brasília. Brasília. 2013.

19. Türel Ermertcan A, Temeltaş G, Deveci A, Dinç G, Güler HB, Oztürkcan S. Sexual dysfunction in patients with psoriasis. J Dermatol. 2006;33(11):772-778.

20. Molina-Leyva A, Almodovar-Real A, Carrascosa JC, et al. Distribution pattern of psoriasis, anxiety and depression as possible causes of sexual dysfunction in patients with moderate to severe psoriasis. An Bras Dermatol. 2015;90(3):338-345.

21. Meeuwis KAP, Potts Bleakman A, van de Kerkhof PCM, et al. Prevalence of genital psoriasis in patients with psoriasis. J Dermatolog Treat. 2018:1-7.

22. Al-Mazeedi K, El-Shazly M, Al-Ajmi HS. Impact of psoriasis on quality of life in Kuwait. Int J Dermatol. 2006;45(4):418-424.

23. Guenther L, Han C, Szapary P, et al. Impact of ustekinumab on healthrelated quality of life and sexual difficulties associated with psoriasis: results from two phase III clinical trials. J Eur Acad Dermatol Venereol. 2011;25(7):851-857.

24. Russo PA, Ilchef R, Cooper AJ. Psychiatric morbidity in psoriasis: a review. Australas J Dermatol. 2004;45(3):155-161.

25. Mercan S, Altunay IK, Demir B, Akpinar A, Kayaoglu S. Sexual dysfunctions in patients with neurodermatitis and psoriasis. $J$ Sex Marital Ther. 2008;34(2):160-168.

26. Sarbu MI, Tampa M, Sarbu AE, Georgescu SR. Sexual Dysfunctions in Psoriatic Patients. Journal of Mind and Medical Sciences. 2014:1(1).

27. Ruiz-Villaverde R, Sánchez-Cano D, Rodrigo JR, Gutierrez CV. Pilot study of sexual dysfunction in patients with psoriasis: influence of biologic therapy. Indian J Dermatol. 2011;56(6):694-699.

28. bssm.org.uk. Hackett G, Dean J, Kell P. British society for sexual medicine guidelines on the management of erectile dysfunction. Available from: www.bssm.org.uk/downloads/BSSM_ED_Management_Guidelines_2007. Accessed October 31, 2018.

29. Galati MCR, Alves Jr. Edeo, Delmaschio ACC, Horta Aldem. Sexualidade e qualidade de vida em homens com dificuldades sexuais. Psico-USF. 2014;19(2):242-252.

30. Meuleman EJ, Diemont WL. Investigation of erectile dysfunction. Diagnostic testing for vascular factors in erectile dysfunction. Urol Clin North Am. 1995;22(4):803-819.

31. Cabete J, Torres T, Vilarinho T, Ferreira A, Selores M. Erectile dysfunction in psoriasis patients. Eur J Dermatol. 2014;24(4):82-486.

32. Eltaweel A, Mustafa AI, El-Shimi OS, Algaod FA. Sex hormones, erectile dysfunction, and psoriasis; a bad friendship! Int J Dermatol. 2018.

33. Feldman HA, Goldstein I, Hatzichristou DG, Krane RJ, Mckinlay JB. Impotence and its medical and psychosocial correlates: results of the massachusetts male aging study. J Urol. 1994;151(1):54-61.
34. Goulding JM, Price CL, Defty CL, Hulangamuwa CS, Bader E, Ahmed I. Erectile dysfunction in patients with psoriasis: increased prevalence, an unmet need, and a chance to intervene. Br J Dermatol. 2011;164(1):103-109.

35. Henseler T, Christophers E. Disease concomitance in psoriasis. $J$ Am Acad Dermatol. 1995;32(6):982-986.

36. Neimann AL, Shin DB, Wang X, et al. Prevalence of cardiovascular risk factors in patients with psoriasis. $J$ Am Acad Dermatol. 2006;55(5):829-835.

37. Qureshi AA, Choi HK, Setty AR, Curhan GC. Psoriasis and the risk of diabetes and hypertension: a prospective study of US female nurses. Arch Dermatol. 2009;145(4):379-382.

38. Naldi L, Chatenoud L, Linder D, et al. Cigarette smoking, body mass index, and stressful life events as risk factors for psoriasis: results from an Italian case-control study. $J$ Invest Dermatol. 2005;125(1):61-67.

39. Gelfand JM, Neimann AL, Shin DB, et al. Risk of myocardial infarction in patients with psoriasis. JAMA. 2006;296(14):1735-1741.

40. Mehta NN, Azfar RS, Shin DB, et al. Patients with severe psoriasis are at increased risk of cardiovascular mortality: cohort study using the General Practice Research Database. Eur Heart J. 2010;31(8):1000-1006.

41. Thompson IM, Tangen CM, Goodman PJ, et al. Erectile dysfunction and subsequent cardiovascular disease. JAMA. 2005;294(23): 2996-3002.

42. Watts GF, Chew KK, Stuckey BG. The erectile-endothelial dysfunction nexus: new opportunities for cardiovascular risk prevention. Nat Clin Pract Cardiovasc Med. 2007;4(5):263-273.

43. Jackson G, Boon N, Eardley I, et al. Erectile dysfunction and coronary artery disease prediction: evidence-based guidance and consensus. Int J Clin Pract. 2010;64(7):848-857.

44. Chen YJ, Chen CC, Lin MW, et al. Increased risk of sexual dysfunction in male patients with psoriasis: a nationwide population-based follow-up study. J Sex Med. 2013;10(5):1212-1218.

45. Bardazzi F, Odorici G, Ferrara F, Magnano M, Balestri R, Patrizi A. Sex and the PASI: patients affected by a mild form of psoriasis are more predisposed to have a more severe form of erectile dysfunction. $J$ Eur Acad Dermatol Venereol. 2016;30(8):1342-1348.

46. Egeberg A, Mallbris L, Gislason G, Hansen PR, Mrowietz U. Risk of periodontitis in patients with psoriasis and psoriatic arthritis. J Eur Acad Dermatol Venereol. 2017;31(2):288-293.

47. Su NY, Huang JY, Hu CJ, Yu HC, Chang YC. Increased risk of periodontitis in patients with psoriatic disease: a nationwide population-based retrospective cohort study. Peer J. 2017;5:e4064.

48. Zuo Z, Jiang J, Jiang R, et al. Effect of periodontitis on erectile function and its possible mechanism. $J$ Sex Med. 2011;8(9):2598-2605.

49. Sanson MAS, Santos FA, Otuki MF. Association between psoriasis and periodontal disease: a literature review. Braz J Periodontol. 2017;27(4):46-56.

50. Batista Rdasm, Zandonade E, Roelke LH. Associação entre doença periodontal e aterosclerose subclínica: uma revisão sistemática. J Vasc Bras. 2011;10(3):229-238.

51. Menter A, Korman NJ, Elmets CA, et al. Guidelines of care for the management of psoriasis and psoriatic arthritis. J Am Acad Dermatol. 2011;65(1):137-174.

52. Bakardzhiev I, Pehlivanov G, Kavaklieva S. Psoriasis Penis - A Two Case Report. Webmed Central Dermatology. 2012;3(3).

53. Theodosiou G, Svensson $\AA$. Methotrexate-associated sexual dysfunction: two case reports. Acta Derm Venereol. 2017;97(9):1132-1133.

54. Aguirre MA, Vélez A, Romero M, Collantes E. Gynecomastia and sexual impotence associated with methotrexate treatment. J Rheumatol. 2002;29(8):1793-1794.

55. Blackburn WD, Alarcón GS. Impotence in three rheumatoid arthritis patients treated with methotrexate. Arthritis Rheum. 1989;32(10):1341-1342.

56. Allocca M, Gilardi D, Fiorino G, et al. Sexual and reproductive issues and inflammatory bowel disease: a neglected topic in men. Eur J Gastroenterol Hepatol. 2018;30(3):316-322.

57. Rossi M, Pellegrino M. Acitretin-associated erectile dysfunction: a case report. Cases J. 2009;2:210. 
58. Katz HI, Waalen J, Leach EE. Acitretin in psoriasis: an overview of adverse effects. J Am Acad Dermatol. 1999;41(3 Pt 2):S7-S12.

59. Tirado Sánchez A, León Dorantes G. Erectile dysfunction during isotretinoin therapy. Actas Urol Esp. 2005;29(10):974-976.

60. Sturkenboom MC, Middelbeek A, de Jong van den Berg LT, van den Berg PB, Stricker BH, Wesseling H. Vulvo-vaginal candidiasis associated with acitretin. J Clin Epidemiol. 1995;48(8):991-997.

61. Colombo D, Banfi G, Cassano N, et al. The Gender attention observational study: gender and hormonal status differences in the incidence of adverse events during cyclosporine treatment in psoriatic patients. Adv Ther. 2017;34(6):1349-1363.
62. Dong X, Zheng Y, Shi TY, Liu HY. Effects of tumor necrosis factoralpha on sexual activity of male patients with ankylosing spondylitis. Clin Rheumatol. 2015;34(5):915-920.

63. Ryan C, Menter A, Guenther L. Efficacy and Safety of Ixekizumab in a randomized, double-blinded, placebo-controlled phase $3 \mathrm{~b}$ study of patients with moderate-to-severe genital psoriasis. Br J Dermatol. 2018.

64. Wylie G, Evans CD, Gupta G. Reduced libido and erectile dysfunction: rarely reported side-effects of methotrexate. Clin Exp Dermatol. 2009;34(7):e234.

\section{Publish your work in this journal}

Psoriasis: Targets and Therapy is international, peer-reviewed, open access journal focusing on psoriasis, nail psoriasis, psoriatic arthritis and related conditions, identification of therapeutic targets and the optimal use of integrated treatment interventions to achieve improved outcomes

\section{Dovepress}

and quality of life. Visit http://www.dovepress.com/testimonials.php to read real quotes from published authors. 